\title{
The Determination of Lepidopterous Pest Species and Their Distributions, Densities, and Damages in Corn Fields of Iğdır Province in Turkey*
}

\author{
Celalettin GÖZÜAÇIK ${ }^{1}$
}

\begin{abstract}
This study was carried out in first and second crop corn fields in order to determine the lepidopterous pest species in 29 corn fields of Iğdır province of East Anatolia Region in 2013-2014 years. In this study was applied in visual inspection method. The sampling were done in 5 adjacent plants on the same row in 5 different points of field. During studies, a total of 1404 larvae were collected and their adults were reared at the laboratory. As a result of study, Black cutworm, Agrotis ipsilon Hufnagel, Beet armyworm, Spodoptera exigua (Hübner), Loreyi leafworm, Acantholeucania loreyi (Duponchel), Cotton bollworm, Helicoverpa armigera (Hübner) (Noctuidae) and European corn borer, Ostrinia nubilalis (Hübner) (Crambidae) were determined. The rate of the species in the composition of these lepidopterous species, as A. ipsilon $0.93 \%, H$. armigera $30.5 \%$, S. exigua $27.9 \%$, A. loreyi $34.1 \%$, O. nubilalis $6.6 \%$ were found. It was found S. exigua damaged in the first and second crop and H. armigera and $O$. nubilalis in second crop. In addition, this study has been the first study on corn pests in Iğdır province.
\end{abstract}

Key words: Corn, Lepidopterous pest species, densities, damage state, Iğdır, Turkey

\section{Iğdır ilinde Mısır Alanlarında Zararlı Lepidoptera Türleri, Dağılımları, Yoğunlukları ve Zarar Durumlarının Belirlenmesi}

ÖZET: Bu çalışma, 2013 ve 2014 yıllarında Iğdır ilinde birinci ve ikinci ürün mısır alanlarında 29 tarlada yürütülmüştür. Örneklemeler, her tarlanın 5 farklı noktasında aynı sıra üzerinde 5 farklı bitki kontrol edilerek yapılmıştır. Çalışmalar süresince toplam 1404 larva toplanmış ve laboratuvarda kültüre alınarak erginleri elde edilmiştir. Sonuçta, Lepidoptera takımına ait Agrotis ipsilon Hufnagel, Spodoptera exigua (Hübner), Acantholeucania loreyi (Duponchel), Helicoverpa armigera (Hübner) (Noctuidae) ve Ostrinia nubilalis (Hübner) (Crambidae) türleri elde edilmiştir. Bu türlerin populasyon içerisindeki dağılımları A. ipsilon \% 0.93, H. armigera $\%$ 30.5, S. exigua \% 27.9, A. loreyi \% 34.1 ve O. nubilalis \% 6.6 olarak belirlenmiştir. Bu türlerden $S$. exigua birinci ve ikinci ürün mısır bitkisinde, $H$. armigera ve $O$. nubilalis ise ikinci üründe zararının önemli olabileceği bulunmuştur. Ayrıca, bu çalışma ilk defa Iğdır ili mısır alanlarında yürütülmüştür.

Anahtar kelimeler: Mısır, Lepidopter türler, yoğunluğu, zarar durumu, Iğdır, Türkiye

\footnotetext{
* Presented at 2nd International Symposium For Agriculture And Food (Isaf 2015), 7-9 October 2015 Ohrid, Republic of Macedonia, as oral presentation.

1 Iğdır Üniversitesi, Ziraat Fakültesi, Bitki Koruma, Iğdır, Türkiye

Sorumlu yazar/Corresponding Author: Celalettin GÖZÜAÇIK, cgozuacik46@gmail.com
} 


\section{INTRODUCTION}

Corn, Zea mays (L.) is a significant plant used in several areas in industry in addition to human and animal nutrition. While approximately 65$70 \%$ of its consumption is used for animal feed, $20 \%$ is used in sugar, starch, and oil industry and the remaining is used in food sector (Özcan, 2009). Corn is mainly cultivated cereal as the main crop and second crop after wheat and barley among the crops in Turkey. According to data of 2013, cultivation area of Turkey is approximately 580000 hectares and its production amount is about 5.1 million tons (USDA, 2013). In Turkey, Eastern Anatolia Region is one of the regions where corn is cultivated at least due to its geographical structure. The microclimate characteristic prevailing in I $\breve{g} \mathrm{~d} ı r$ province in this region allows many agricultural products to grow. In recent years, cultivation of corn as both grain and for silage in the province has rapidly become prevalent after 2010 because of its simple production and subsidy. While corn was cultivated for silage in an area of 1160.6 hectares in total from 2001 to 2009 (Anonymous, 2009), in 2012 corn was cultivated in an area of 6436.3 ha in total for silage (3288.5 ha) and grain (3147.8 ha), and corn silage of 163.425 tones and grain corn of 24.67 tones were cultivated (TUIK, 2013).

As is in the other plants, corn plant is attacked by numerous pests in the field and economic yield loss occurs sometimes. Primary harmful ones for corn plant among the pest species are lepidopterous species. While European corn borer and corn stalk borer cause about $5 \%$ yield loss in first crop of corn (Güllü, 2000), They cause yield loss up to $100 \%$ of the second crop or late planted corn (Tsitsipis, 1988). Agrotis ipsilon, A. segetum Schiffermüller, Sesamia nonagrioides Lefebvre, S. cretica Lederer, Mythimna (Acantholeucania) loreyi, True Armyworm, Mytimna (Pseudaletia unipuncta) Haworth, Spodoptera exigua, Spodoptera littoralis Boisduval, and Helicoverpa armigera species have been determined as lepidopterous species harmful to corn in Turkey up to now (Lodos, 1981; Özdemir and Uzunali, 1981; Zeren et al., 1988; Şimşek and Güllü, 1992; Kayapınar and Kornoşor, 1992; Güllü, 2000; Gözüaçık and Mart, 2005). This study was conducted in 2012 and 2013 for the first time in order to determine harmful species of lepidopterous to corn and their loss status in Iğdır Province.

\section{MATERIALS AND METHODS}

Studies were conducted in 2013 and 2014 at 29 corn fields, in which the corn was planted for silage and grain in Center, Aralık, Karakoyunlu, and Tuzluca districts of Iğdır Province. While the fields in which the corn was second crop were visited once a week, those in which the corn was first crop were visited once in different phenological stages including leaf, pre-tasseling, tasseling, ear and grain formation, milk, yellow, and dense formation stages (Hanway, 1966).

Larvae of lepidopterous were obtained from eaten or cut plants above 3 meters at 5 different points in corn field for underground pests in vegetative development stage of plant; from stem, leaf, and anther of totally 25 corn plants at 5 different points as 5 adjacent plants from each point in generative stage; and from stems and generative organs of totally 25 corn plants at 5 different points in each corn fields as 5 adjacent plants from each point in maturity stage (Güllü, 2000). Obtained samples were brought to laboratory in ice buckets with their label information and classified. They were cultured in plastic boxes covered with cheesecloth in climate room at $25 \pm 2{ }^{\circ} \mathrm{C}$ and $65 \pm 5 \%$ relative humidity. Stems, leaves, and ears of daily fresh corn were given to larvae for feeding. Butterflies emerging from cultures were prepared for the identification.

\section{RESULTS AND DISCUSSION}

In this study, 1404 larvae belonging to order of harmful lepidopterous to first and second crop corn fields were collected in corn fields of Iğdır Province in 2013 and 2014 years. Agrotis ipsilon, H. armigera, S. exigua, A. loreyi (Noctuidae) and O. nubilalis (Hübner) (Crambidae) were obtained (Table 1). 
Table 1. Lepidopterous species and numbers in corn fields of Iğdır province in 2013 and 2014.

\begin{tabular}{|l|l|c|c|c|}
\hline \multirow{2}{*}{ Common name } & \multirow{2}{*}{ Scientific name } & \multicolumn{3}{|c|}{ The number of larvae } \\
\cline { 3 - 5 } & & $\mathbf{2 0 1 3}$ & $\mathbf{2 0 1 4}$ & Total \\
\hline Black cutworm & Agrotis ipsilon & 4 & 9 & 33 \\
\hline Beet armyworm & Spodoptera exigua & 38 & 354 & 392 \\
\hline Loreyi Leafworm & Acantholeucania loreyi & 44 & 385 & 429 \\
\hline European corn borer & Ostrinia nubilalis & 14 & 78 & 92 \\
\hline Cotton bollworm & Helicoverpa armigera & 17 & 461 & 478 \\
\hline Total & & $\mathbf{1 5 7}$ & $\mathbf{1 2 4 7}$ & $\mathbf{1 4 0 4}$ \\
\hline
\end{tabular}

According to Table 1, in totally percentages, A. ipsilon, H. armigera, S. exigua, A. loreyi, and O. nubilalis were found as $0.93 \%, 30.5 \%, 27.9 \%$, $34.1 \%$, and $6.6 \%$, respectively. In 2013, 157 larvae from lepidopterous species were collected and their percentage distributions were determined as follows; A. ipsilon $2.5 \%$, H. armigera $10.8 \%$, S. exigua $24.2 \%$, A. loreyi $28 \%$, and O. nubilalis $8.9 \%$. In 2014, 1247 larvae from lepidopterous species were collected and their percentage distributions were recorded as follows; A. ipsilon $0.7 \%, \mathrm{H}$. armigera $37 \%$, S. exigua $28.4 \%$, A. loreyi $30.9 \%$, and $O$. nubilalis $6.3 \%$. In the study conducted by Gözüaçık and Mart (2005) in Southeastern Anatolia Region of Turkey in 2003 and 2004, they stated that $A$. loreyi $35.0-55.2 \%$ took place in the first rank in terms of the densities of lepidopterous species harmful to first crop corn, which was followed by $S$. exigua 8.8 $44 \%$, O. nubilalis $18.7-0.0 \%$, S. cretica $16.3-1.2 \%, A$. segetum $13.7-1.2 \%, S$. nonagrioides $5.0-1.0 \%$, and $A$. ipsilon 2.5-1.2\%; whereas $A$. loreyi $41.1-12.3 \%$ took place in the first rank for the second crop corn, which was followed by $S$. cretica $28.0-27.5 \%$, S. exigua 6.5 $31.3 \%$, S. nonagrioides $17.2-7.4 \%$, O. nubilalis 6.6$1.5 \%$, A. segetum, and A. ipsilon $1.0-0.0 \%$.

Lepidopterous pests were found at lower rate in first crop corn in the studies. However, 162 larvae of S. exigua in total were collected from a first crop corn field of 130 hectares adjacent to the river Aras on the border of Armenia in Tuzluca between 20.4.2014 and 25.4.2014.It was found that $A$. ipsilon and $A$. loreyi had the lowest and highest density respectively, in both years. Sesamia species were not found in corn fields of Iğdır. Tables 2 and 3 illustrate numbers of lepidopterous species obtained from first and second crop corn fields in Iğdır Province in 2013-2014 and their locations.

Table 2. The number of collected Lepidopterous species from the first crop corn at different locations of Iğdır province in 2013 and 2014

\begin{tabular}{|c|c|c|c|c|c|c|c|c|c|c|}
\hline \multirow{2}{*}{ Villages } & \multicolumn{2}{|c|}{ A. ipsilon } & \multicolumn{2}{|c|}{ S. exigua } & \multicolumn{2}{|c|}{ A. loreyi } & \multicolumn{2}{|c|}{ O. nubilasis } & \multicolumn{2}{|c|}{ H. armigera } \\
\hline & 2013 & 2014 & 2013 & 2014 & 2013 & 2014 & 2013 & 2014 & 2013 & 2014 \\
\hline Sarıçoban & - & 2 & - & 2 & - & - & - & - & - & - \\
\hline Kuzugüden & - & - & 10 & - & - & 8 & 3 & 5 & 1 & 3 \\
\hline Çalpala & - & - & - & - & - & 14 & - & 1 & - & 3 \\
\hline Bayraktutan & - & - & - & 2 & - & - & - & - & 1 & - \\
\hline Y.Çarıkçı & - & - & - & - & - & 2 & - & - & - & 3 \\
\hline A.Çarıkçı & - & - & - & - & - & - & - & - & - & 2 \\
\hline Özdemir & 2 & - & - & - & - & - & - & - & - & 1 \\
\hline Aras mah & - & - & - & - & - & 3 & - & - & - & - \\
\hline Saraçlı & - & - & - & - & - & 9 & - & - & - & 1 \\
\hline Center & - & - & - & - & 3 & 2 & - & 1 & - & - \\
\hline Zülfikar & - & - & 6 & - & - & 2 & - & - & - & - \\
\hline Tuzluca & - & 7 & 0 & 162 & 3 & - & - & - & - & - \\
\hline Total & 2 & 9 & 16 & 166 & 6 & 40 & 3 & 7 & 2 & 13 \\
\hline
\end{tabular}


Table 3. Collected lepidopterous species and number from the second crop corn from different locations of Iğdır province in 2013 and 2014.

\begin{tabular}{|c|c|c|c|c|c|c|c|c|c|c|}
\hline \multirow[t]{2}{*}{ Villages } & \multicolumn{2}{|c|}{ A. ipsilon } & \multicolumn{2}{|c|}{ S. exigua } & \multicolumn{2}{|c|}{ M. loreyi } & \multicolumn{2}{|c|}{ O. nubilasis } & \multicolumn{2}{|c|}{ H. armigera } \\
\hline & 2013 & 2014 & 2013 & 2014 & 2013 & 2014 & 2013 & 2014 & 2013 & 2014 \\
\hline Çalpala & - & - & 3 & 41 & 7 & 11 & - & - & - & 1 \\
\hline Bayraktutan & - & - & - & - & 8 & 136 & 4 & 52 & - & 1 \\
\hline Kasımcan & 1 & - & - & 1 & - & 10 & 4 & 4 & - & 3 \\
\hline Küllük & - & - & - & - & - & 124 & & 6 & - & 1 \\
\hline Hakmehmet & - & - & - & - & - & 11 & 2 & 4 & - & 5 \\
\hline Alikamerli & - & - & 3 & - & 11 & 25 & 1 & & - & \\
\hline A.Çarıkçı & - & - & - & - & - & - & - & - & - & 2 \\
\hline Melekli & - & - & - & - & 3 & - & - & - & 1 & 10 \\
\hline Erhacı & - & - & - & - & - & - & - & - & & 13 \\
\hline Saraçlı & 1 & - & - & - & - & - & - & - & 6 & 244 \\
\hline Ramazankent & - & - & - & - & 9 & 10 & - & - & - & 101 \\
\hline Aras mah & - & - & - & 26 & - & - & - & - & 2 & 16 \\
\hline Karakoyun & - & - & - & - & - & 18 & & 3 & 1 & 4 \\
\hline Cennetabat & - & - & - & - & - & - & - & 2 & - & 1 \\
\hline Taşburun & - & - & 16 & 120 & - & - & - & - & - & 1 \\
\hline Y.Alican & - & - & - & - & - & - & - & - & - & 2 \\
\hline Gaziler & - & - & - & - & - & - & - & - & 5 & 43 \\
\hline Total & 2 & - & 22 & 188 & 38 & 345 & 11 & 71 & 15 & 448 \\
\hline
\end{tabular}

The highest number of $S$. exigua was obtained as 120 larvae from Taşburun on 22.7.2014. The highest numbers of $A$. loreyi was obtained as 136 larvae from Bayraktutan on 27.6.2014 and as 124 larvae from Küllük on 29.7.2014. The highest number of $O$. nubilasis was obtained as 52 larvae from Bayraktutan on 27.6.2014 in second crop corn field. The highest numbers of $H$. armigera were collected as 244 larvae in three corn fields from Saraçlı on 19.8.2014 and as 101 larvae from Ramazankent on 20.8.2014. Density was found to be higher in second crop compared to first crops.

Hence Derin (1982) stated that in, O. nubilalis had economic importance Izmir province and its surrounding. Also Özpınar (1992) indicated that $O$. nubilalis and, $S$. nonagrioides caused important yield loss in Mediterranean and Aegean Regions. When both tables (Tables 2 and 3) were evaluated; 157 larvae were found in 2013, whereas this number was found higher with 1247 larvae in 2014. Some of the reasons for this can be considered as follows; the gradual increase in corn cultivation, pests find continuously fresh food because the producers extend over the plantation stage of silage corn, winter was being more mild in 2014 compared to 2013, and the decrease of lepidopterous pests due to intense pesticide applications in early stages of corn.
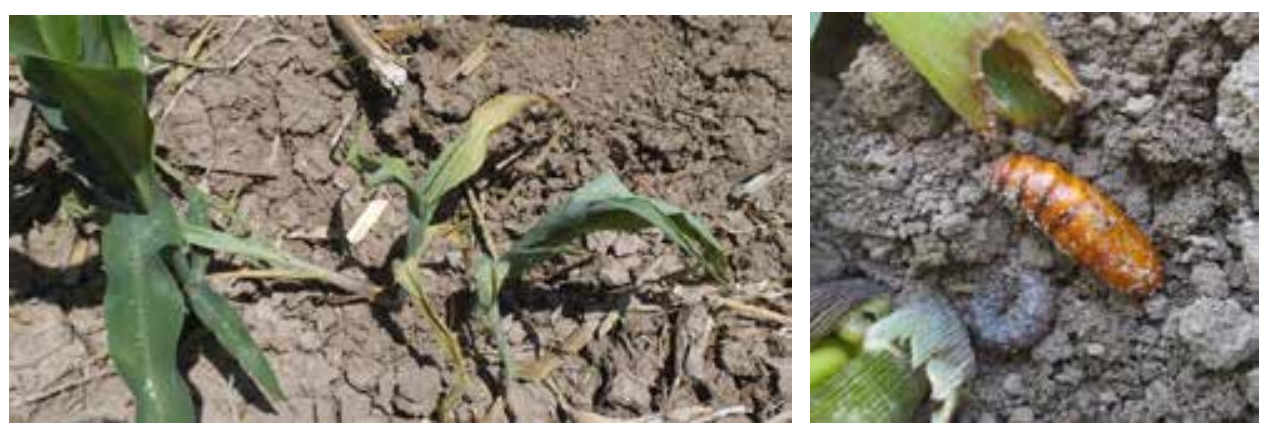

Figure 1. Damage and larvae/pupae of Agrotis ipsilon in plant row 
Agrotis ipsilon, in both years, was found in 4-8 leaves of the first crop corn plant in $3^{\text {rd }}$ week of April and $1^{\text {st }}$ week of May in Tuzluca district and Sarıçoban subject to city centre. Archer and Musick (1977) stated that corn plant tended to be harmed by A. ipsilon from its emergence to the $4^{\text {th }}$ leaves (early whorl), likewise, Güllü (2000) reported that corn plant tended to be harmed by Agrotis spp from its emergence to the 2-4 leaves stages in Çukurova Region. When the years 2013 and 2014 in Iğdır province were evaluated, it was observed that fields of first crop at the rate of $25 \%$ and second crop fields at the rate of $11.8 \%$ were infected with $A$. ipsilon. However, it was understood that in both years density of larvae was quite below the economic threshold,two or three cut plants or leaves in $10 \mathrm{ft}$ row at several sites throughout a field (Sisson et. al., 2012), and the harm was insignificant.

Spodoptera exigua was found in 4-8 leaves of the plant for first and second crop corn in both years. Güllü (2000) stated that corn plant tended to be harmed by $S$. exigua from its emergence to the 2-4 leaves and 4-6 leaves stages in Çukurova Region. Sertkaya et al. (2004) indicated that this pest was harmful in emergence of the plant as much as in the stage with 8 leaves. Larvae were determined in $3^{\text {rd }}$ and $4^{\text {th }}$ weeks of April for the first crop, and in late June and early July for second crop in four districts where the study was conducted.
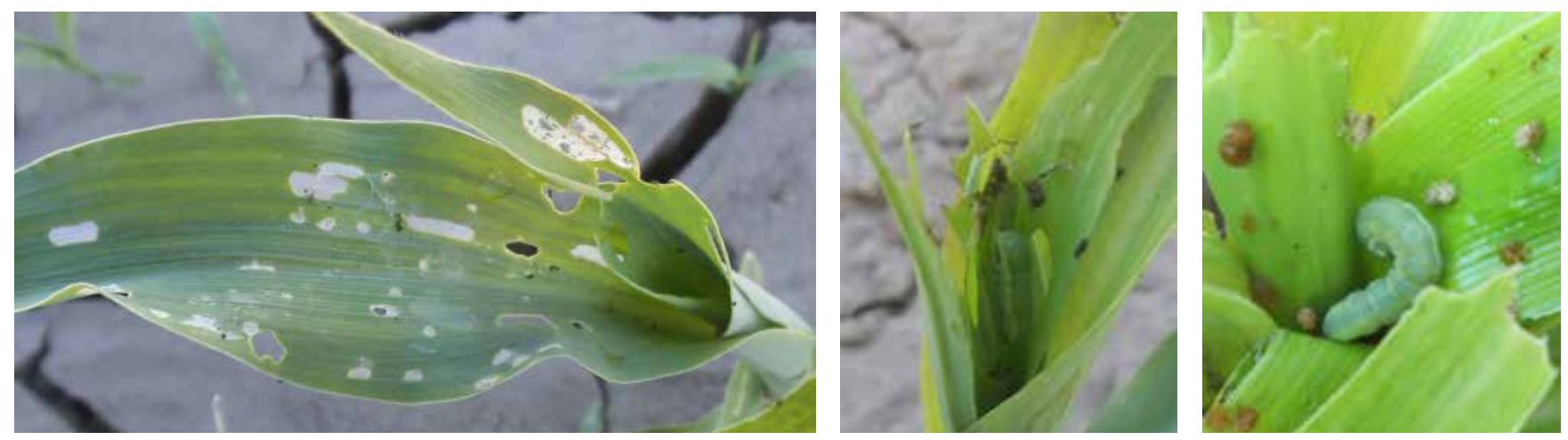

Figure 2. Damage and larvae of Spodoptera exigua

When the years 2013 and 2014 in Iğdır province were evaluated, it was observed that fields of first crop at the rate of $41.7 \%$ and second crop fields at the rate of $29.4 \%$ were infected with $S$. exigua. In the study conducted by Atlihan et al. (2003) on potato fields in Van province in 1998-1999, pests caused epidemic in 1998 and reached to highest population level within the season in late June in Erciş district and in early July for Muradiye district; however, population density was quite lower in 1999. In Taşburun, it was recorded that $S$. exigu reached to 0.96 larva/plant density for second crop corn. It was especially more harmful to late planted corn fields (Gözüaçık, 2009). However, in this study mean 1.3 larva/plant of $S$. exigua was found for the first crop in Tuzluca in 2014. It was observed that there were serious damages in this field. The reason for this has been reported that the pest is epidemically sporadic species and caused serious harm because its population developed rapidly in some years (Smith, 1989; Huffman, 1996; Tisdale and Sappington 2001).
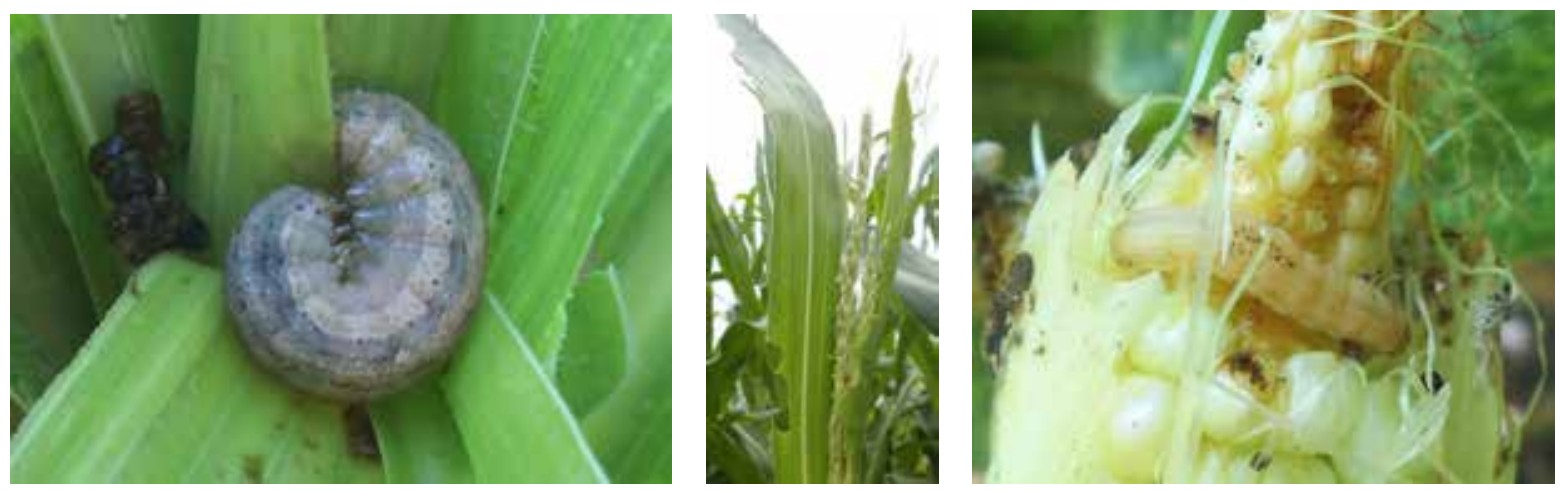

Figure 3. Damage and larvae of Acantholeucania loreyi 
Acantholeucania loreyi was the most common pest in corn fields of Iğdır province. When two-year studies were evaluated, it was observed that corn lands were infected with $A$. loreyi at the rate of $66.7 \%$ for first crop and at the rate of $52.9 \%$ for second crop. Density was counted as 1.1 larva/plant in Bayraktutan and 1.0 larva/ plant in Küllük. Ram Singh et al. (1988) investigated emergence frequency of $M$. separata and $M$. loreyi on corn, sugarcane, and white millet in India and reported that 1-3 larva/plant population caused severe harm, so green parts of corn and sugarcane plants were damaged. It was observed that larvae fed with centre and fresh leaves of the corn in $6^{\text {th }}, 7^{\text {th }}$, and $8^{\text {th }}$ developmental stages of plant, as well as grains on tip of ear in milk formation stage of ear and tassel (Hanway, 1966). Among the pest species of corn, A. loreyi is particularly important on second crop maize, because it significantly reduces yields if it attacks the crop just before silking and pollination (Kornoşor, 1999).

In this study, larvae of Ostrinia nubilalis were especially found in $5^{\text {th }}, 6^{\text {th }}, 7^{\text {th }}, 8^{\text {th }}$, and $9^{\text {th }}$ stages (generative and maturation stages) of second crop corn plant. In the study conducted by Derin (1982) in Izmir province and its surrounding, it was reported $O$. nubilalis had economic significance. Özpınar (1992) reported that $O$. nubilalis caused important losses in Mediterranean and Aegean Regions.
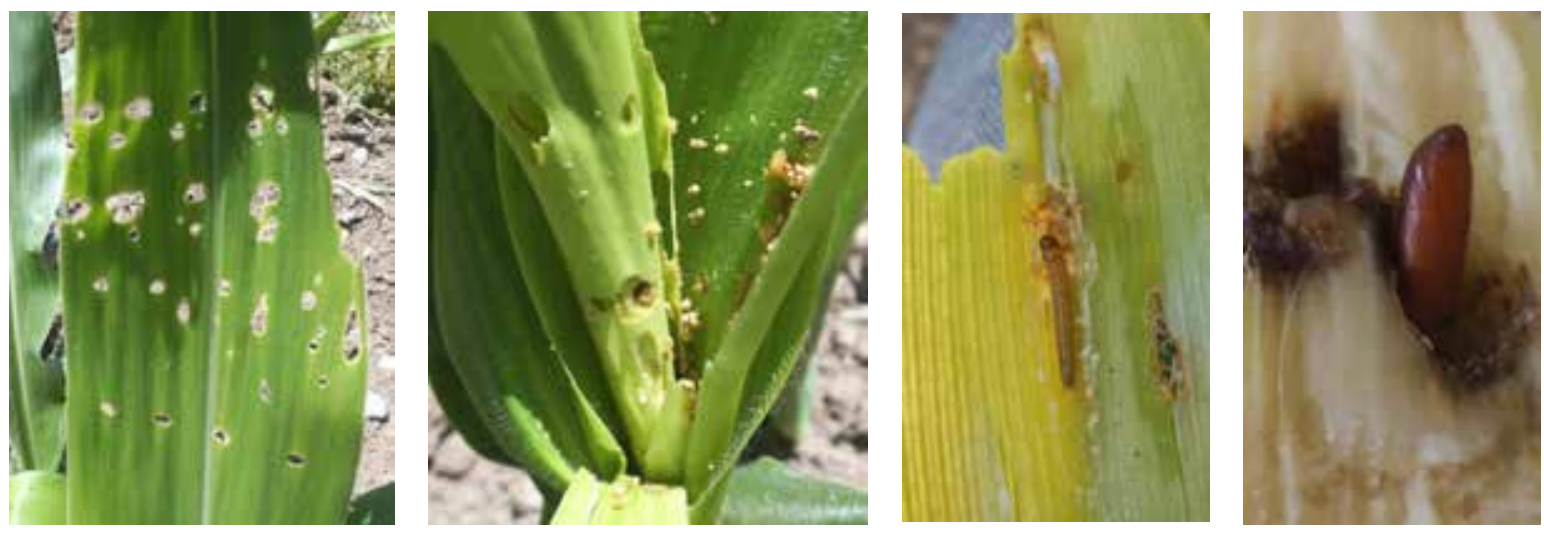

Figure 4. Damage and larvae/pupae of Ostrinia nubilalis

This pest reached the highest number with 0.4 larvae/plant in Bayraktutan among corn lands of Iğdır province. Zeren et. al. (1989) stated that this pest considerably threatens the cultivation of second crop corn in Çukurova and causes infection at the rate of $73.4 \%$ in Adana. In the study conducted by Bigler and Bosshart (1992) between 1971-1991 in Switzerland, they reported that $O$. nubilalis caused infection of $73 \%$ for corn plant, led infection of $83 \%$ for grain corn and $66 \%$ for silage corn, economic loss was $34.1 \%$ for grain corn and $10.1 \%$ for silage corn in 1991 . It was found that this pest infected first crop corn fields at the rate of $25 \%$ and second crop corn fields at the rate of $41.2 \%$ in both years in Iğdır. Because cultivation of corn plant is recently introduced in province, it is thought that it can become a threat for second crop corn in future years. While it was done $70 \%$ of second crop corn production in Çukurova region in 2002-2003, production of corn decreased till $30 \%$ due to O. nubilalis and $S$. nonogrioides in 2014 (Cerit et al., 2014).
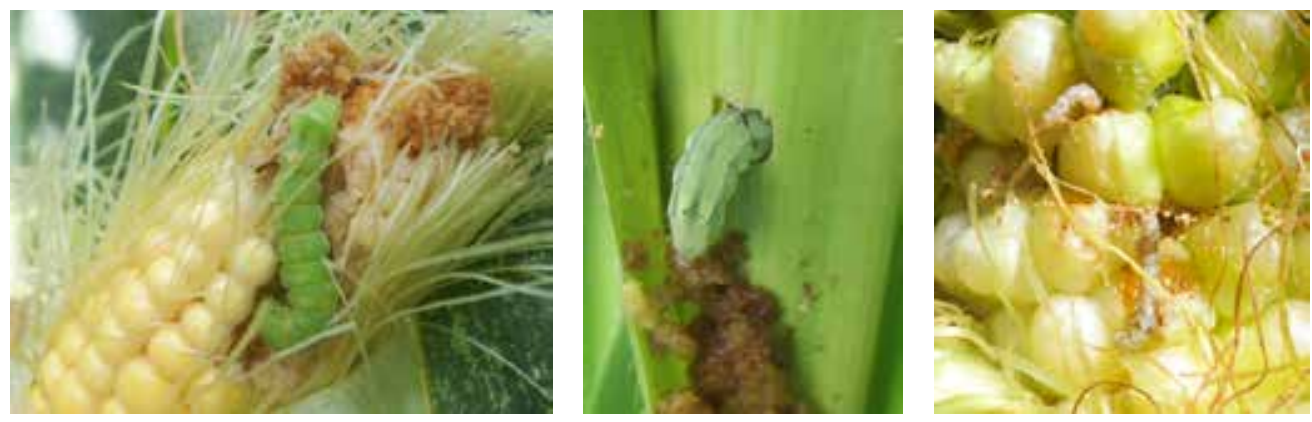

Figure 5. Damage and larvae of Helicoverpa armigera 
Helicoverpa armigera larvae found in $7^{\text {th }}, 8^{\text {th }}$, and $9^{\text {th }}$ growth stages of the plant (generative and maturation stages) for second crop corn. Larvae of this pest cause harm in stages of tassel, and milk formation for the first crop, and late whorl, tassel, and milk formation stages for second crop corn (Güllü, 2000). Mean 0.7 and 0.8 larva/plant was found at most in Saraçlı and Ramazankent in the studies. It has been reported that Bollworm is common in Black Sea, Marmara, Aegean, and Southern Anatolia Regions of Turkey. There is infection almost all in Mediterranean Region (Özdemir and Uzunali, 1981). As 2013 and 2014 years were evaluated for Iğdır province, it was observed that infection of $H$. armigera was present at the rate of $58.3 \%$ for first crop corn fields and $94.1 \%$ for second crop corn fields. It is thought that this can create a risk especially for second crop corn plant. Keszthelyi et al. (2011) reported $14.03 \%$ weight loss in grains and $13.74 \%$ weight loss in cobs of sweet corn, also, loss of corn due to $H$. armigera has been estimated at 262 $\mathrm{kg} \mathrm{ha}^{-1}$ and if larvae damage early silks, pollination will be reduced resulting in even greater yield reductions.

\section{CONCLUSIONS}

Agrotis ipsilon, H. armigera, S. exigua, A. loreyi (Noctuidae), and $O$. nubilalis (Pyralidae) species belonging to Lepidoptera order, which are harmful to corn, were determined in first and second crop corn fields of Iğdır in 2013 and 2014. Spodoptera exigua, $H$. armigera, and $O$. nubilalis were concluded to be threatening for corn fields. Number of larvae was found to be higher for second crop corn in both years. Except for S. exigua, other species were determined to be below economic threshold. It was understood that cultivators did not have adequate knowledge about identifying and managing pests because corn cultivation has been newly introduced in province. Being conducted in corn fields of Iğdır for the first time, this study aimed to determine lepidopterous pests and their harm status, and to raise awareness of cultivators regarding this matter.

\section{ACKNOWLEDGMENT}

This study has been supported by Scientific Research Unit of Iğdır University

\section{REFERENCES}

Anonymous, (2009). Iğdır Tarım İl Müdürlüğü Kayıtları, Iğdır.

Archer, T.L., Musick, G.J. (1977). Cutting potential of the black cutworm on field corn. Journal of economic entomology 70 : $745-747$.

Atlıhan, R, Yardım, E.N., Özgökçe, M.S., Kaydan M.B. (2003). Population dynamic and natural enemies of Spodoptera exigua (Hübner) (Noctuidae: Lepidoptera) in potato fields in Van province. Yuzuncu Yil University Journal Of Agricultural Sciences, 13(1): 39-43.

Bigler, F., Bosshart, S. (1992). The European corn borer in Switzerland - distribution and damage in 1991. Landwirtschaft Schweiz 5(6):287-292

Cerit, İ., Güllü, M., Sarıhan, H., Kanat, A.D., Turkay, M.A., Uçak, A.B. (2006). Misırkurdu (Ostrinia nubilalis Hübner) (Lepidoptera: Crambidae) ve misır koçankurdu (Sesamia nonagrioides Lefebvre) (Lepidoptera: Noctuidae) 'na dayanıklı transgenik mısır çeşidi Pioneer 33P67 (MON 810) $B t^{e e} \operatorname{nin}$ Alan Denemesi Projesi sonuç raporu, Adana, 2006.

Derin, A. (1982). İzmir ilinde Misırkurdu (Ostrinia nubilalis Hub.) (Lep.; Pyralidae)'nun konukçuları, yayılışı, zararı, biyolojisi, ve doğal düşmanlarının saptanması üzerine araştırmalar. Ege Üniversitesi Fen Bilimleri Enstitüsü, Bitki Koruma Anabilim Dalı, Doktora Tezi, İzmir.

Gözüaçık, C., Mart, C. (2005). Güneydoğu Anadolu Bölgesinde mısırda zararlı Lepidoptera türleri, yoğunlukları ve yayılışlarının belirlenmesi üzerinde çalışmalar. Harran Üniversitesi Ziraat Fakültesi Dergisi, 9 (4) 11-16s.

Güllü, M. (2000). Studies on the population developments of harmful Lepidopterous species on different corn varieties in Çukurova. Çukurova Universty, Institute of Natural Resourse (Unpublished Doctorate Thesis), pp. 198.

Hanway, J.J. (1966). How a Corn Plant Develops. Iowa Shte Univ. Coop Ext. Ser. Spec. Rep. 48: 17-18.

Huffman, R. (1996). The beet armyworm in Texas and Oklohama. 1995, Proceedings Beltwide Cotton Conference. National Cotton Council of America, Memphis, TN, 113-115.

Kayapınar, A., Kornoşor, S., 1992. Çukurova Bölgesi'nde Ostrinia nubilalis Hübner (Lep., Pyralidae) ile Sesamia nonagrioides Lefebvre (Lep., Noctuidae)' in yayılıșı ve bitkideki dağılımları. Türkiye II. Entomoloji Kongresi 28-31 Ocak, pp. 491-501. Adana.

Keszthelyi, S., Pal-Fam, F., Kerepesi, I. (2011). Effect of cotton bollworm caused injury on maize grain content. Acta Biol. Hung. 62(1):57-64.

Konak, C. (1988). Planting of maize at different times to reduce Borer damage in Eagen Region, Proceedings of a Symposium on European corn Borers And Control Measures, Adana, s: 21-24, 1-3 November, 1988.

Kornoşor, S. (1999). Entomological problems of maize in Turkey. Proc. XX Conf. International Working Group on Ostrinia and Other Maize Pests (Adana, Turkey), pp. 14-23.

Lodos, N. (1981). Maize pests and their importance in Turkey. EPPO Bulletin, vl. 11, pp. 87-89 
Özcan, S. (2009). Modern dünyanın vazgeçilmez bitkisi mısır: Genetiği değiştirilmiş (Transgenik) mısırın tarımsal üretime katkıs1, Türk Bilimsel Derlemeler Dergisi, 2, 01-34, 2009.

Özdemir, N., Uzunali, S. (1981). Noctuid species causing damage to maize in Turkey. Bulletin Organisation Europe'enne et Mediterrane et Pour la Protection des Plant., 11(2): 97-99.

Özpınar, A. (1992). Mısır zararlılarına karşı yürütülen tüm savaşım çalışmaları. Güney Anadolu Bölgesi'nde İkinci Ürün Tarımı ve Sorunları Sempozyumu (26-28 Ekim), Şanlıurfa.

Sertkaya, E., Bayram, A., Kornoşor, S. (2004). Egg and larval parasitoids of the Beet Armyworm Spodoptera exigua on maize in Turkey Phytoparasitica, 32(3):305-312.

Sisson, A.J., Jesse, Laura, C.H., Hodgson, Erin, W. (2012). "Black Cutworm Scouting Advisory" Integrated Crop Management News. Paper 183.

Smith, R.H. (1989). Experiences with beet armywormcontrol in cotton in 1988. Proceedings, Beltwide Cotton Conference. National Cotton Council of America, Memphis, TN, 273-275.

Şimşek, N., Güllü, M., Zeren, O. (1988). Studies on effectiveness of some agrochemicals against Stem Borers, Sesamia nonagrioides Lef., S. cretica Led. and European Corn Borer, Ostrinia nubilalis Hbn. in Mediterranean Region of Turkey, Proceedings of a Symposium On European corn Borers And Control Measures, Adana s: 44-54, 1-3 November.

Şimşek, N., Sezer, C. (1983). Akdeniz Bölgesinde ikinci ürün olarak ekilen mısırda görülen zararlı ve faydalılar üzerinde sürvey çalışmaları. Adana Zirai Mücadele Araştırma Enstitüsü (Proje No: E/103.657, Nihai Raporu, written in Turkish).

Tisdale, R.A., Sappington, T.W. (2001). Realized and potential fecundity, egg fertility and longevity of laboratory-reared female beet armyworm (Lepidoptera: Noctuidae) under different adult diet regimes. Ann. Entomol. Soc. Am., 94(3): 415-419.

Tsitsipis, J.A. (1988). The Corn Stalk borer, Sesamia nonagrioides: Forecasting, crop loss assesment and pest management, Integrated crop protection in cereals, pp. 171-177, Balkema, Rotherdam, Brookfield, 1988.

TUIK, (2013). Bitkisel üretim istatistikleri. http://www.tuik.gov.tr/ (Acces to: 6.8.2015)

USDA, (2015). http://apps.fas.usda.gov/psdonline/psdQuery.aspx (Acces to: 6.8.2015)

Zeren, Y., Mercan, S., Zeren, O., Şimşek, N., Güllü, M. (1989). Mısır delici kurtlarına karşı ilaçlı mücadele yöntemleri üzerinde araştırmalar. 12. Ulusal Tarımsal Mekanizasyon Kongresi Bildirileri. 1-2 Haziran 1989, Tekirdağ, 157-164. 